\title{
Spontaneous abortions among laboratory workers; a follow up study
}

\author{
LENE ZEUTHEN HEIDAM \\ From the Institute of Community Health, Department of Social Medicine, Odense University, 5000 Odense C, \\ Denmark
}

SUMMARY An investigation was conducted among all female laboratory workers in the county of Funen to test the hypothesis that work in laboratories during pregnancy increases the risk of spontaneous abortion. Laboratory workers from hospital, university, and other public laboratories and from laboratories in industry were investigated. A socially comparable reference group less exposed to chemicals at work included office workers, technical assistants and designers, physiotherapists, and occupational therapists. Information was obtained through a postal questionnaire study in May 1980 and from hospital records. Neither the occupation in any single category of laboratory nor the alleged exposure to any single chemical during pregnancy showed a significant increase in the odds ratio for spontaneous abortion. A selection bias was found among the non-respondents with respect to both occupation and outcome of pregnancy, but the influence on the results was slight, owing to the small number of non-respondents. The higher rates of hospital admission for spontaneous abortion among the cases compared with the controls indicates that register data are not more valid than self reported data. This leads to severab methodological problems that ought to be studied in further detail.

In recent years interest in examining the effect of the occupational environment on human reproduction has grown. The topic is of particular importance because chemicals used in industry are introduced after far fewer tests than are required for the approval of new drugs. Furthermore, the fetus as a developing organism is more susceptible to toxicity than is the mature adult.

In vitro and in vivo studies in animals have shown that many chemicals used in industry may have embryotoxic or fetotoxic effects. ${ }^{1}$ Epidemiological investigations have shown that anaesthetics in a working environment may affect reproductive capacity of personnel working in theatre. ${ }^{1-3}$ Few of these studies, however, have allowed for the potential response rate bias. ${ }^{4}$ Investigations of adverse pregnancy outcome by occupation ${ }^{5-7}$ have been published in recent years, but the results are far from certain, and the methods used are imprecise and insensitive.

Laboratory workers are exposed to many of the chemicals suspected of being embryotoxic such as heavy metals, organic solvents, and carcinogens. ${ }^{1}$
Some studies have found an increased frequency of congenital malformation in children born to laboratory workers, ${ }^{8-10}$ but these findings may be due to chance, since the investigations were started because clusters of chromosome aberrations or adverse pregnancy outcome were noted in the laboratories under study. Conflicting results, however, have been found in studies on populations where a cluster of pregnancy losses had not been observed before the investigations. ${ }^{11-14}$ An increased risk of spontaneous abortions was found in a study of inquest reports among laboratory workers initiated by a cluster of chromosome aberrations ${ }^{15}$ and in an interview study of employees in laboratories where no observations has been done beforehand. ${ }^{18} \mathrm{~A}$ study, not started by any prior findings, did not show an increased risk of spontaneous abortions when a combination of data from inquest and hospital register were used. ${ }^{14}$

The aim of the present investigation is to find out if all female laboratory workers within a county run an increased risk of spontaneous abortions compared with other female employees. The risk of 
spontaneous abortions is estimated using data from inquests and hospital registers.

\section{Materials and methods}

The investigation was based on data from a historical prospective survey of women representing 12 selected occupations within the Danish county of Funen. The criteria for entrance into the study were a minimum of one month's work in one of the selected occupations during the period 1972-80, including those who had left employment during that time, and aged between 18 and 40 in 1980 . The names and the 10-digit personal identification number were taken from employers or trade union records. In May 1980 a postal questionnaire was sent to 6730 women. Any missing returns were followed up by up to two letters and then by up to three telephone calls, resulting in a final response rate of $90 \%$. According to the questionnaire 3362 of the 6063 respondents had been pregnant after 1972 .

Data were collected covering the women's entire reproductive life before May 1980 and their periods of employment. The women were asked for the year of all previous pregnancies and the outcome of each pregnancy: a live birth, a child with an abnormality, including stillbirth, and spontaneous abortion. Finally, questions were asked about each woman's professional education, her occupation of longest duration, employment during each pregnancy, and about chemical exposure in this work. Questions about induced abortions were omitted, not only for the sake of discretion but also since the validity of these answers was expected to be poor.

The present investigation deals with six of the 12 selected occupations. The study population were hospital laboratory workers exposed to chemicals in hospital laboratories and industrial laboratory workers exposed to chemicals at the university, at other public laboratories, or in industrial laboratories. The reference group less exposed to chemicals at work were physiotherapists, occupational therapists, office workers, and technical assistants and designers. Skilled laboratory workers were then compared with other groups of skilled employees of rather similar socioeconomic status. The study group and the reference group were comparable with respect both to work postures and movements of these during a day. Minor subgroups among the controls, however-namely, the office workers who lifted parcels in post offices and the physiotherapists who treated patients-were probably exposed to greater physical strain than the cases.

In the county of Funen there are 11 hospitals all of which participated in the study. One hospital, however, did not submit information on the employees who had left until they agreed to enter the study: 47 of the 66 women agreed. The university of Odense helped in the study and 40 out of a total of 42 private or public establishments employing industrial laboratory workers participated. Part of the reference group was chosen from the same workplaces. The physiotherapists, occupational therapists, and office workers were taken from the 11 hospitals and other office workers were identified through the university and through the 40 private or public establishments. In addition, office workers were chosen from six factories which participated in the study and from the post offices in Odense. The technical assistants and designers were identified through their trade union. Table 1 presents the response rates among the six occupational groups.

Table 1 Reply rates on postal questionnaires

\begin{tabular}{lcc}
\hline & $\begin{array}{l}\text { No of questionnaires } \\
\text { sent }\end{array}$ & $\begin{array}{l}\text { No (\%) of } \\
\text { replies received }\end{array}$ \\
\hline $\begin{array}{l}\text { Hospital laboratory } \\
\text { workers }\end{array}$ & 457 & $444(97)$ \\
$\begin{array}{l}\text { Industrial laboratory } \\
\text { workers }\end{array}$ & 424 & $401(95)$ \\
$\begin{array}{l}\text { Total reference group: } \\
\text { Office workers }\end{array}$ & 1571 & $1431(91)$ \\
$\begin{array}{l}\text { Technical assistants } \\
\text { and designers }\end{array}$ & 803 & $739(92)$ \\
$\begin{array}{l}\text { Physiotherapists } \\
\begin{array}{l}\text { Occupational } \\
\text { theraptists }\end{array}\end{array}$ & 597 & $533(89)$ \\
\hline
\end{tabular}

The analysis of the questionnaire data related only to the pregnancies where the woman worked in one of the above mentioned occupations and women who had their first pregnancy in $\mathbf{1 9 7 2}$ or later. Gravidity, the total number of pregnancies that the woman had experienced at the end of the follow up period in 1980 , was considered as a potential confounder ${ }^{17} 18$ that had to be controlled.

The Odense hospital maintains a computerised registry of all patients discharged from hospitals in the county of Funen. The registry contains a 10-digit personal identification number and information of diagnosis, date of admission, and hospital of treatment. By means of the personal identification number information was obtained from the registry on all women in the survey who had been treated for spontaneous abortion (diagnoses No 631, 643, and 645), for induced abortion (diagnoses No 640-642), or who gave birth (diagnoses No 650-662) between 1 January 1973 and 30 June 1980. Diagnoses were based on the International Classification of Disease, 
8th revision.

If a patient had been admitted twice within three imonths with different diagnoses she was included only under her first diagnosis. The diagnoses Nos 645.3 (haemorrhagia post abortum) and 645.9 (abortus alius) do not classify the abortion as spontaneous or induced. It was considered, however, that the abortions were most likely to be spontaneous, and they were categorised accordingly. This was less than $3 \%$ of the total number of spontaneous abortions.

In Funen all births and induced abortions are treated in hospital, whereas only some of the spontaneous abortions are treated in hospital.

Registration data were analysed on respondents and non-respondents who were reported to have had a pregnancy after 1 January 1972; these were analysed by the occupational title stated in the questionnaire as this was also known for nonrespondents.

The rate of spontaneous abortions is defined as the number of spontanous abortions divided by the number of spontaneous abortions plus the number of births and expressed as a percentage. Odds ratio (OR), the risk estimate of spontanous abortions, is the odds of the number of spontaneous abortions to the number of births in a group of laboratory workers divided by the corresponding odds in the reference group. The $95 \%$ confidence intervals of OR are indicated in parentheses.

\section{Results}

The analysis of the questionnaire data shows that the crude ORs of spontaneous abortions by occupation in the different laboratories tend to be less than unity (table 2). In laboratories in industry and in public establishments the OR is slightly increased, but this is not statistically significant. Controlling for gravidity, pregnancy order, and the woman's age at the time of the pregnancy using a logistic regression model does not change the ORs substantially.

Table 3 shows the risks of spontaneous abortion among the laboratory workers according to exposure as recorded in the questionnaire (women answering yes to the question about exposure to a specific chemical during pregnancy in comparison with the laboratory workers who answered no, don't know, or did not answer). Women in most of the exposure categories have no increased risk of spontaneous abortion. Only exposure to cadmium, corrosive agents, or one of the agents in the group such as colorants, aromatic nitrocompounds, or vinyl chloride show an increased $O R$. These are not statistically significant. Adjusting for gravidity, pregnancy order, and the woman's age at the time of
Table 2 Odds ratio of self reported spontaneous abortion in laboratory workers who worked in different types of laboratories during pregnancy, compared with women who worked in a reference occupation during pregnancy $195 \%$ confidence limits in parentheses)

\begin{tabular}{|c|c|c|c|c|c|}
\hline Place of work & $\begin{array}{l}\text { No of } \\
\text { pregnancies }\end{array}$ & $\begin{array}{l}\text { No of } \\
\text { spontaneous } \\
\text { abortions }\end{array}$ & $\begin{array}{l}\text { No of } \\
\text { births }\end{array}$ & $\begin{array}{l}\text { Odds rati } \\
\text { Crude }\end{array}$ & $\begin{array}{l}\text { Controlled } \\
\text { for gravidity, } \\
\text { pregnancy } \\
\text { order, and } \\
\text { age }\end{array}$ \\
\hline $\begin{array}{l}\text { Reference } \\
\text { occupation }\end{array}$ & 843 & 84 & 759 & $1 \cdot 0$ & $1 \cdot 0$ \\
\hline $\begin{array}{l}\text { Cinical chemistry, } \\
\text { hospital }\end{array}$ & 182 & 13 & 169 & $\begin{array}{c}0.7 \\
(0 \cdot 3-1 \cdot 3)\end{array}$ & $\begin{array}{c}0.7 \\
(0.4-1.4)\end{array}$ \\
\hline $\begin{array}{l}\text { Pathology, } \\
\text { hospital }\end{array}$ & 36 & 3 & 33 & $\begin{array}{c}0 \cdot 8 \\
(0 \cdot 2-2 \cdot 7)\end{array}$ & $\begin{array}{c}0.5 \\
(0 \cdot 1-1 \cdot 7)\end{array}$ \\
\hline $\begin{array}{l}\text { Blood bank and } \\
\text { other hospital } \\
\text { laboratories }\end{array}$ & 41 & 3 & 38 & $\begin{array}{c}0.7 \\
(0 \cdot 1-2 \cdot 3)\end{array}$ & $\begin{array}{c}0.6 \\
(0 \cdot 2-2 \cdot 0)\end{array}$ \\
\hline $\begin{array}{l}\text { Laboratories in } \\
\text { industry and } \\
\text { public } \\
\text { establishments }\end{array}$ & 91 & 10 & 81 & $\begin{array}{c}1 \cdot 1 \\
(0 \cdot 5-2 \cdot 3)\end{array}$ & $\begin{array}{c}1 \cdot 2 \\
(0 \cdot 6-2 \cdot 5)\end{array}$ \\
\hline $\begin{array}{l}\text { Laboratories at } \\
\text { university }\end{array}$ & 115 & 9 & 106 & $\begin{array}{c}0.8 \\
(0.3-1 \cdot 6)\end{array}$ & $\begin{array}{c}0.7 \\
(0 \cdot 3-1 \cdot 5)\end{array}$ \\
\hline
\end{tabular}

the pregnancy did not change the ORs substantially.

In table 4 the risks of spontaneous abortions are estimated using the hospital data on spontaneous abortions and births. Among the respondent industrial laboratory workers the crude $O R$ of spontaneous abortion is increased to a not statistically significant $O R$ of 1.4 , and among the respondent hospital laboratory workers it is 1.0 compared with the reference group. Furthermore, table 4 shows that the rate of spontaneous abortions among the non-respondent industrial laboratory workers tends to be lower than among the respondents, and in the reference group the opposite is found. None of the differences, however, was found to be statistically significant at the 0.05 level. The crude $O R$ is decreased from 1.4 to 1.3 for industrial laboratory workers, when the pregnancies among the non-respondents are added to the respondents' data (table 4). Among the non-respondent hospital laboratory workers the rate of spontaneous abortions tends to be higher than among the respondents, but the difference is not statistically significant at the 0.05 level. The number of pregnancies among the non-respondent hospital laboratory workers is small and by including these data with the respondents' data the crude OR do not change. Control for the woman's age at the time of the pregnancy did not change the ORs.

Within the exposed occupations the rates of self 
Table 3 Odds ratio self reported spontaneous abortions in laboratory workers exposed to a specific chemical during

\begin{tabular}{|c|c|c|c|c|c|c|}
\hline \multirow{3}{*}{$\begin{array}{l}\text { Exposed } \\
\text { Organic } \\
\text { solvents }\end{array}$} & & & \multirow{3}{*}{$\begin{array}{l}\begin{array}{l}\text { No of } \\
\text { spontaneous } \\
\text { abortions }\end{array} \\
20 \\
18\end{array}$} & \multirow{3}{*}{$\begin{array}{c}\begin{array}{c}\text { No of } \\
\text { births }\end{array} \\
279 \\
148\end{array}$} & \multicolumn{2}{|l|}{ Odds ratio } \\
\hline & $\begin{array}{l}\text { No of } \\
\text { pregnancies }\end{array}$ & rancies & & & Crude & $\begin{array}{l}\text { Controlled } \\
\text { for gravidity, } \\
\text { pregnancy } \\
\text { order, and } \\
\text { age }\end{array}$ \\
\hline & $\begin{array}{l}\text { Yes } \\
\text { No }\end{array}$ & $\begin{array}{l}299 \\
166\end{array}$ & & & $\begin{array}{c}0.6 \\
(0.3-1.2)\end{array}$ & $\begin{array}{c}0.7 \\
(0.3-1 \cdot 4)\end{array}$ \\
\hline Lead & $\begin{array}{l}\text { Yes } \\
\text { No }\end{array}$ & $\begin{array}{r}39 \\
426\end{array}$ & $\begin{array}{r}3 \\
35\end{array}$ & $\begin{array}{r}36 \\
391\end{array}$ & $\begin{array}{c}0.9 \\
(0 \cdot 2-3 \cdot 2)\end{array}$ & $\begin{array}{c}0.9 \\
(0 \cdot 2-3 \cdot 2)\end{array}$ \\
\hline Cadmium & $\begin{array}{l}\text { Yes } \\
\text { No }\end{array}$ & $\begin{array}{r}18 \\
447\end{array}$ & $\begin{array}{r}2 \\
36\end{array}$ & $\begin{array}{r}16 \\
411\end{array}$ & $\begin{array}{c}1 \cdot 4 \\
(0 \cdot 2-6 \cdot 5)\end{array}$ & $\begin{array}{c}1 \cdot 1 \\
(0 \cdot 2-5 \cdot 9)\end{array}$ \\
\hline Mercury & $\begin{array}{l}\text { Yes } \\
\text { No }\end{array}$ & $\begin{array}{l}114 \\
351\end{array}$ & $\begin{array}{r}8 \\
30\end{array}$ & $\begin{array}{l}106 \\
321\end{array}$ & $\begin{array}{c}0.8 \\
(0.3-1 \cdot 9)\end{array}$ & $\begin{array}{c}1.0 \\
(0.4-2 \cdot 3)\end{array}$ \\
\hline Selenium & $\begin{array}{l}\text { Yes } \\
\text { No }\end{array}$ & $\begin{array}{r}13 \\
452\end{array}$ & $\begin{array}{r}0 \\
38\end{array}$ & $\begin{array}{r}13 \\
414\end{array}$ & $\begin{array}{c}0 \\
(0 \cdot 0-3 \cdot 8)\end{array}$ & $\begin{array}{c}0 \\
(0 \cdot 0-5 \cdot 4)\end{array}$ \\
\hline Benzidine & $\begin{array}{l}\text { Yes } \\
\text { No }\end{array}$ & $\begin{array}{l}112 \\
353\end{array}$ & $\begin{array}{r}5 \\
33\end{array}$ & $\begin{array}{l}107 \\
320\end{array}$ & $\begin{array}{c}0.5 \\
(0.1-1 \cdot 2)\end{array}$ & $\begin{array}{c}0.5 \\
(0.2-1 \cdot 4)\end{array}$ \\
\hline $\begin{array}{l}\text { Toluidine } \\
\text { compounds }\end{array}$ & $\begin{array}{l}\text { Yes } \\
\text { No }\end{array}$ & $\begin{array}{l}165 \\
300\end{array}$ & $\begin{array}{r}9 \\
29\end{array}$ & $\begin{array}{l}156 \\
271\end{array}$ & $\begin{array}{c}0.5 \\
(0 \cdot 2-1 \cdot 2)\end{array}$ & $\begin{array}{c}0 \cdot 5 \\
(0 \cdot 2-1 \cdot 1)\end{array}$ \\
\hline Haematest & $\begin{array}{l}\text { Yes } \\
\text { No }\end{array}$ & $\begin{array}{r}75 \\
390\end{array}$ & $\begin{array}{r}3 \\
35\end{array}$ & $\begin{array}{r}72 \\
355\end{array}$ & $\begin{array}{c}0.4 \\
(0 \cdot 1-1 \cdot 4)\end{array}$ & $\begin{array}{c}0.5 \\
(0.1-1.7)\end{array}$ \\
\hline Azocompounds & $\begin{array}{l}\text { Yes } \\
\text { is No }\end{array}$ & $\begin{array}{r}83 \\
382\end{array}$ & $\begin{array}{r}7 \\
31\end{array}$ & $\begin{array}{r}76 \\
351\end{array}$ & $\begin{array}{c}1.0 \\
(0.4-2 \cdot 7)\end{array}$ & $\begin{array}{c}1 \cdot 1 \\
(0 \cdot 4-2 \cdot 7)\end{array}$ \\
\hline $\begin{array}{l}\alpha \text {-naphty- } \\
\text { lamine }\end{array}$ & $\begin{array}{l}\text { Yes } \\
\text { No }\end{array}$ & $\begin{array}{r}34 \\
431\end{array}$ & $\begin{array}{r}1 \\
37\end{array}$ & $\begin{array}{r}33 \\
394\end{array}$ & $\begin{array}{c}0 \cdot 3 \\
(0 \cdot 0-2 \cdot 1)\end{array}$ & $\begin{array}{c}0 \cdot 3 \\
(0 \cdot 0-2 \cdot 3)\end{array}$ \\
\hline $\begin{array}{l}\text { B-naphty- } \\
\text { lamine }\end{array}$ & $\begin{array}{l}\text { Yes } \\
\text { No }\end{array}$ & $\begin{array}{r}16 \\
449\end{array}$ & $\begin{array}{r}1 \\
37\end{array}$ & $\begin{array}{r}15 \\
412\end{array}$ & $\begin{array}{c}0.7 \\
(0 \cdot 0-5 \cdot 1)\end{array}$ & $\begin{array}{c}0.5 \\
(0 \cdot 1-4 \cdot 5)\end{array}$ \\
\hline $\begin{array}{l}\text { Other } \\
\text { compounds of } \\
\text { naphta }\end{array}$ & $\begin{array}{l}\text { Yes } \\
\text { No }\end{array}$ & $\begin{array}{r}12 \\
453\end{array}$ & $\begin{array}{r}0 \\
38\end{array}$ & $\begin{array}{r}12 \\
415\end{array}$ & $\begin{array}{c}0 \\
(0 \cdot 0-4 \cdot 1)\end{array}$ & $\begin{array}{c}0 \\
(0 \cdot 0-5 \cdot 6)\end{array}$ \\
\hline
\end{tabular}

reported and of hospital registered spontaneous abortions are similar (table 5). The crude OR of self reported versus hospital registered spontaneous abortion is $0.9(0.5-1.7)$ within the group of hospital laboratory workers, and within the industrial laboratory group the corresponding crude $O R$ is 0.9 $(0 \cdot 6-1 \cdot 6)$. In the reference group, however, the spontaneous abortions reported by the women are more frequent than the hospital registered spontaneous abortions, and the crude OR of self reported versus hospital registered spontaneous abortions $1 \cdot 3(1 \cdot 0-1 \cdot 7)$ is of borderline statistical significance.

The crude ORs of self reported spontaneous abortion analysed by the woman's occupational title when she entered the survey is $0.8(0.5-1 \cdot 1)$ for hospital laboratory workers and $1.0(0.7-1.5)$ for industrial laboratory workers compared with the reference group, and are similar to the crude ORs pregnancy, compared with non-exposed laboratory workers (95\% confidence limits in parentheses)

\begin{tabular}{|c|c|c|c|c|c|c|}
\hline \multirow[b]{2}{*}{ Exposed to } & \multirow{2}{*}{\multicolumn{2}{|c|}{$\begin{array}{l}\text { No of } \\
\text { pregnancies }\end{array}$}} & \multirow[b]{2}{*}{$\begin{array}{l}\text { No of } \\
\text { spontaneous } \\
\text { abortions }\end{array}$} & \multirow[b]{2}{*}{$\begin{array}{l}\text { No of } \\
\text { births }\end{array}$} & \multicolumn{2}{|l|}{ Odds ratio } \\
\hline & & & & & Crude & $\begin{array}{l}\text { Controlled } \\
\text { for gravidity, } \\
\text { pregnancy } \\
\text { order, and } \\
\text { age }\end{array}$ \\
\hline Propionacid & $\begin{array}{l}\text { Yes } \\
\text { No }\end{array}$ & $\begin{array}{r}59 \\
406\end{array}$ & $\begin{array}{r}4 \\
34\end{array}$ & $\begin{array}{r}55 \\
372\end{array}$ & $\begin{array}{c}0.8 \\
(0.2-2 \cdot 4)\end{array}$ & $\begin{array}{c}0.9 \\
(0.3-2.9)\end{array}$ \\
\hline $\begin{array}{l}\text { Acryl } \\
\text { compounds }\end{array}$ & $\begin{array}{l}\text { Yes } \\
\text { No }\end{array}$ & $\begin{array}{r}29 \\
436\end{array}$ & $\begin{array}{r}1 \\
37\end{array}$ & $\begin{array}{c}28 \\
399\end{array}$ & $\begin{array}{c}0.4 \\
(0.0-2 \cdot 5)\end{array}$ & $\begin{array}{c}0 \cdot 3 \\
(0 \cdot 0-2 \cdot 6)\end{array}$ \\
\hline $\begin{array}{l}\text { Aceto- } \\
\text { compounds }\end{array}$ & $\begin{array}{l}\text { Yes } \\
\text { No }\end{array}$ & $\begin{array}{l}114 \\
351\end{array}$ & $\begin{array}{r}8 \\
30\end{array}$ & $\begin{array}{l}106 \\
321\end{array}$ & $\begin{array}{c}0.8 \\
(0.3-1.9)\end{array}$ & $\begin{array}{c}0.9 \\
(0.4-2.0)\end{array}$ \\
\hline $\begin{array}{l}\text { Cyanid } \\
\text { compounds }\end{array}$ & $\begin{array}{l}\text { Yes } \\
\text { No }\end{array}$ & $\begin{array}{l}203 \\
262\end{array}$ & $\begin{array}{l}11 \\
27\end{array}$ & $\begin{array}{l}192 \\
235\end{array}$ & $\begin{array}{c}0.5 \\
(0 \cdot 2-1 \cdot 1)\end{array}$ & $\begin{array}{c}0 \cdot 5 \\
(0 \cdot 2-1 \cdot 0)\end{array}$ \\
\hline $\begin{array}{l}\text { Epoxy } \\
\text { compounds }\end{array}$ & $\begin{array}{l}\text { Yes } \\
\text { No }\end{array}$ & $\begin{array}{r}28 \\
437\end{array}$ & $\begin{array}{c}0 \\
38\end{array}$ & $\begin{array}{r}28 \\
399\end{array}$ & $\begin{array}{c}0 \\
(0 \cdot 0-1 \cdot 6)\end{array}$ & $\begin{array}{c}0 \\
(0 \cdot 0-4 \cdot 2)\end{array}$ \\
\hline PCB & $\begin{array}{l}\text { Yes } \\
\text { No }\end{array}$ & $\begin{array}{r}7 \\
458\end{array}$ & $\begin{array}{r}0 \\
38\end{array}$ & $\begin{array}{r}7 \\
420\end{array}$ & $\begin{array}{c}0 \\
(0 \cdot 0-8 \cdot 0)\end{array}$ & $\begin{array}{c}0 \\
(0.0-6 \cdot 6)\end{array}$ \\
\hline Isotopes & $\begin{array}{l}\text { Yes } \\
\text { No }\end{array}$ & $\begin{array}{r}40 \\
425\end{array}$ & $\begin{array}{r}3 \\
35\end{array}$ & $\begin{array}{r}37 \\
390\end{array}$ & $\begin{array}{c}0.9 \\
(0 \cdot 2-3 \cdot 1)\end{array}$ & $\begin{array}{c}0.7 \\
(0 \cdot 2-2 \cdot 4)\end{array}$ \\
\hline $\begin{array}{l}\text { Colorants, } \\
\text { aromatic } \\
\text { nitrocom- } \\
\text { pounds, or } \\
\text { vinylchloride }\end{array}$ & $\begin{array}{l}\text { Yes } \\
\text { No }\end{array}$ & $\begin{array}{r}11 \\
454\end{array}$ & $\begin{array}{c}1 \\
37\end{array}$ & $\begin{array}{r}10 \\
417\end{array}$ & $\begin{array}{c}1 \cdot 1 \\
(0 \cdot 0-8 \cdot 3)\end{array}$ & $\begin{array}{c}2 \cdot 0 \\
(0 \cdot 2-17 \cdot 7)\end{array}$ \\
\hline $\begin{array}{l}\text { Corrosive } \\
\text { agents }\end{array}$ & $\begin{array}{l}\text { Yes } \\
\text { No }\end{array}$ & $\begin{array}{r}28 \\
437\end{array}$ & $\begin{array}{r}3 \\
35\end{array}$ & $\begin{array}{r}25 \\
402\end{array}$ & $\begin{array}{c}1 \cdot 4 \\
(0 \cdot 3-4 \cdot 9)\end{array}$ & $\begin{array}{c}2 \cdot 5 \\
(0 \cdot 6-9 \cdot 5)\end{array}$ \\
\hline $\begin{array}{l}\text { Other potential } \\
\text { mutagens }\end{array}$ & $\begin{array}{l}1 \text { Yes } \\
\text { No }\end{array}$ & $\begin{array}{r}4 \\
461\end{array}$ & $\begin{array}{r}0 \\
38\end{array}$ & $\begin{array}{r}4 \\
423\end{array}$ & $\begin{array}{c}0 \\
(0.0-17 \cdot 4)\end{array}$ & $\begin{array}{l}0 \\
-\end{array}$ \\
\hline $\begin{array}{l}\text { Potentially } \\
\text { dangerous } \\
\text { agents }\end{array}$ & $\begin{array}{l}\text { Yes } \\
\text { No }\end{array}$ & $\begin{array}{r}5 \\
460\end{array}$ & $\begin{array}{r}0 \\
38\end{array}$ & $\begin{array}{r}5 \\
422\end{array}$ & $\begin{array}{c}0 \\
(0 \cdot 0-12 \cdot 5)\end{array}$ & $\begin{array}{l}0 \\
-\end{array}$ \\
\hline
\end{tabular}

analysed by the woman's occupation during pregnancy (table 2). After controlling for the woman's age at the time of the pregnancy the OR for hospital laboratory worker $0.8(0.9-1.9)$ and $O R$ for the industrial laboratory workers $1.0(0.7-1.5)$ are unchanged.

\section{Discussion}

The possibility that exposure to certain chemicals in the working environment do harm the embryo ${ }^{1}$ prompted this survey; the prompting came not from a cluster of adverse pregnancy outcomes noted in the laboratories studied but from observations at other places.

This study does not support the hypothesis of a general increased risk of spontaneous abortion among laboratory workers in this geographical area. Neither is the work in any of the categories of 
Table 4 Odds ratio of hospital registered spontaneous abortions in laboratory workers compared with the reference group for respondents and non-respondents $195 \%$ confidence limits in parentheses)

\begin{tabular}{|c|c|c|c|c|}
\hline \multirow[b]{2}{*}{ Occupation } & \multirow[b]{2}{*}{$\begin{array}{l}\text { No of } \\
\text { pregnancies }\end{array}$} & \multirow[b]{2}{*}{$\begin{array}{l}\text { No (\%) of } \\
\text { spontaneous } \\
\text { abortions }\end{array}$} & \multicolumn{2}{|l|}{ Odds ratio } \\
\hline & & & Crude & $\begin{array}{l}\text { Controlled } \\
\text { for age }\end{array}$ \\
\hline $\begin{array}{l}\text { Respondents: } \\
\text { Reference group }\end{array}$ & 921 & $95(10.3)$ & $1 \cdot 0$ & $1 \cdot 0$ \\
\hline $\begin{array}{l}\text { Hospital laboratory } \\
\text { workers }\end{array}$ & 222 & $23(10 \cdot 4)$ & $\begin{array}{c}1 \cdot 0 \\
(0 \cdot 6-1 \cdot 6)\end{array}$ & $\begin{array}{c}1 \cdot 0 \\
(0 \cdot 6-1 \cdot 6)\end{array}$ \\
\hline $\begin{array}{l}\text { Industrial laboratory } \\
\text { workers }\end{array}$ & 225 & $31(13 \cdot 8)$ & $\begin{array}{c}1 \cdot 4 \\
(0 \cdot 9-2 \cdot 2)\end{array}$ & $\begin{array}{c}1 \cdot 4 \\
(0 \cdot 9-2 \cdot 2)\end{array}$ \\
\hline $\begin{array}{l}\text { Non-respondents: } \\
\text { Reference group }\end{array}$ & 67 & $11(16.4)$ & & \\
\hline $\begin{array}{l}\text { Hospital laboratory } \\
\text { workers }\end{array}$ & 7 & $2(28.6)$ & & \\
\hline $\begin{array}{l}\text { Industrial laboratory } \\
\text { workers }\end{array}$ & 13 & $1(7 \cdot 7)$ & & \\
\hline \multicolumn{5}{|l|}{ Total: } \\
\hline Reference group & 988 & $106(10 \cdot 7)$ & 1.0 & 1.0 \\
\hline $\begin{array}{l}\text { Hospital laboratory } \\
\text { workers }\end{array}$ & 229 & $25(10.9)$ & $\begin{array}{c}1.0 \\
(0.6-1 \cdot 6)\end{array}$ & $\begin{array}{c}1 \cdot 0 \\
(0.7-1 \cdot 7)\end{array}$ \\
\hline $\begin{array}{l}\text { Industrial laboratory } \\
\text { workers }\end{array}$ & 238 & $32(13.4)$ & $\begin{array}{c}1 \cdot 3 \\
(0 \cdot 8-2 \cdot 0)\end{array}$ & $\begin{array}{c}1 \cdot 3 \\
(0 \cdot 9-2 \cdot 0)\end{array}$ \\
\hline
\end{tabular}

Table 5 Respondents' self reported spontaneous abortions compared with their hospital registered spontaneous abortions

\begin{tabular}{lcc}
\hline Occupation & $\begin{array}{l}\text { No of } \\
\text { pregnancies }\end{array}$ & $\begin{array}{l}\text { No(\%) of } \\
\text { spontaneous } \\
\text { abortions }\end{array}$ \\
\hline $\begin{array}{l}\text { Self reported: } \\
\text { Reference group }\end{array}$ & 1329 & $167(12 \cdot 6)$ \\
Hospital laboratory workers & 390 & $38(9 \cdot 7)$ \\
Industrial laboratory workers & 353 & $45(12 \cdot 7)$ \\
Registered at hospital: & 921 & $95(10 \cdot 3)$ \\
Reference group & 222 & $23(10 \cdot 4)$ \\
Hospital laboratory workers & 225 & $31(13.8)$ \\
\hline Industrial laboratory workers & & \\
\hline
\end{tabular}

The small number of hospital registered pregnancies compared with self reported pregnancies is due to two factors: only pregnancies registered at the hospitals within the county of Funen are included and the register period is one year shorter, 1973 to 30 June 1980 than the period of self reported pregnancies, 1982 to mid-1980.

laboratory described here associated with an enhanced risk of spontaneous abortion. Working in a university's laboratories during pregnancy did not enhance the risk of spontaneous abortion, and this is in accordance with the findings of a study of selected laboratories at Göteborg University. ${ }^{14}$ The negative findings are probably not due to an enhanced risk among women in the reference occupation, since their rate of hospital admitted spontaneous abortions $10.7 \%$ (table 4 ) is below the rate in the total Danish population $12 \% .^{19}$

The information on chemical exposure is imprecise, and the intensity of exposure and the time of exposure in the pregnancy is not known. The exposure specific ORs below 1 indicate, however, that the exposures do not increase the risk of spontaneous abortion much, or that only minor subgroups run a high risk. In conclusion, however, it cannot be ruled out that some processes necessitating extensive exposure of laboratory workers may be dangerous to the embryo.

The respondents' data were found to be slightly biased, since a modest selection was seen in the nonrespondents group with respect both to the occupation and outcome of pregnancy. The selection was statistically insignificant, but the nonrespondents were few. As expected non-respondents among industrial laboratory workers had few spontaneous abortions whereas non-respondentso among the controls had many spontaneous abortions. $\stackrel{\mathbb{\Omega}}{\Omega}$ The response bias had the same direction as was found in a study of anaesthetic exposure and spontaneous abortions ${ }^{4}$ and tends to exaggerate the ORs among the respondents, but in contrast to Axelsson and Rylander correction of the bias hardly changed the ORs, probably because of the small number of non-respondents.

The significantly increased OR of self reported versus hospital registered spontaneous abortions seen in the reference group, but not in the exposed groups, is the opposite of what was expected and indicates negative information bias. Nevertheless, the findings may have other interpretations. In the present study the laboratory workers' better medical insight may imply that more cases than controls are admitted to hospital when they experience an early spontaneous abortion, which may be difficult to distinguish from a delayed menstruation. A study on the validity of hospital data on spontaneous abortions ${ }^{20}$ showed that the percentage of spontaneous abortions in the hospital register of all spontaneous abortions reported in the questionnaire were positively associated with the duration of the woman's education, possibly due to better medical insight. The hospital data would then be biased towards too high risk estimates of spontaneous abortion in the case group.

Another possible explanation is that the cases may elect induced abortion at an earlier gestational age compared with controls, and then relatively more 
spontaneous abortions of late gestation, which all tend to be admitted to hospital, ${ }^{20}$ would be left among cases compared with controls.

In this study the rate of induced abortions among respondent hospital laboratory workers 7.9\% (19 of 241 pregnancies) and among industrial laboratory workers $8.5 \%(21 / 246)$ are slightly lower than the rate for controls $9 \cdot 5 \%(97 / 1018)$. This means that the ORs are slightly underestimated.

The findings of this investigation are unlike other studies which have shown an increased risk of spontaneous abortions among laboratory workers. ${ }^{15} 16$ This discrepencey could depend on several factors. One study worked with a selected population. ${ }^{15}$ None of the two studies took into account response rate bias. Possibly also the degree and nature of exposure differed in the investigated laboratories as compared with the laboratories in this study.

The present study indicates that data on hospital registered spontaneous abortions are not more valid than self reported data. Only a part of the occuring spontaneous abortions are recognised by the women, and of these not all are registered at hospital. This leads to several methodological problems that ought to be studied in further detail.

\section{References}

${ }^{1}$ Heidam LZ. Fosterskader og kemikalier $i$ arbejdsmiljøet. Odense universitets forlag, 1978. (In Danish.)

${ }^{2}$ Corbett TH, Cornell RG, Endrez JL, Lieding K. Birth defects among children of nurse-anaesthetists. Anesthesiology 1974; 41: 341-4.

${ }^{3}$ Tomlin PJ. Health problems of anaesthetists and their families in the West Midlands. Br Med J 1979; i: 77984.

Axelsson G, Rylander R. Exposure to anaesthetic gases and spontaneous abortions: response bias in a postal questionnaire study. Int J Epidemiol 1982; 11: 250-6.
${ }^{5}$ Hemminki K, Franssila E, Vainio H. Spontaneous abortions among female chemical workers in Finland. Int Arch Occup Environ Health 1980; 45: 123-6.

${ }^{6}$ Hemminki $\mathbf{K}$, Niemi ML, Koskinen $\mathbf{K}$, Vainio $\mathbf{H}$. Spontaneous abortions among women employed in the metal industry in Finland. Int Arch Occup Environ Health 1980; 47: 53-60.

${ }^{7}$ Nordström S, Beckman L, Nordenson I. Occupational and environmental risks in and around a smelter in northern Sweden. III. Frequency of spontaneous abortions. Hereditas 1978; 88: $51-4$.

B Jansa S, Tillberg J, Källén B, Wende H. Fosterskador iakttagne vid Astras kemiska kontrollaboratorium. Läkartidningen 1978; 75: 22.

'Hansson E, Jansa S, Wande H, Källén B, Östlund E. Pregnancy outcome for women working in laboratories in some of the pharmaceutical industries in Sweden. Scand J Work Environ Health 1980; 6: 131-4.

${ }^{10}$ Blomqvist $U$, Ericson $A$, Källén B, Westerholm P. Delivery outcome for women working in the pulp and paper industries. Scand J Work Environ Health 1981; 7: 114-8.

${ }^{11}$ Meirik O, Källén B, Gauffín U, Ericson A. Major malformations in infants born of women who worked in laboratories while pregnant. Lancet 1979; ii: 91.

${ }^{12}$ Ericson A, Källén B, Meirik, O, Westerholm P. Gastrointestinal atresia and maternal occupation during pregnancy. JOM 1982; 24: 515-8.

${ }^{13}$ Olsen J. Risk of exposure to teratogens amongst laboratory staff and painters. Danish Medical Bulletin 1983; 30: 24-8.

${ }^{14}$ Axelson G, Lütz C, Rylander R. Exposure to solvents and pregnancy outcome among university laboratory employees. Br J Ind Med (in press).

${ }^{15}$ Kolmodin-Hedman B, Hedströ̀m L. Enkätundersøkning hos kemikalieexponerad laboratoriepersonal rörande spontanaborter. Läkarttidningen 1978; 75: 3044-5.

${ }^{16}$ Strandberg M, Sandbäck K, Axelson O, Sundell L. Spontaneous abortions among women in hospital laboratory. Lancet 1978: i: 384-5.

${ }^{17}$ Olsen J, Heidam LZ. Analysis of pathologic outcome of pregnancies. Scand J Soc Med 1983; 11: 3-6.

${ }^{18}$ Heidam LZ. Spontaneous abortions among factory workers. The importance of gravidity control. Scand J Soc Med (in press).

${ }^{10}$ Medical statistics of births, 1974, 1977, and 1979. National Health Service.

${ }^{20}$ Niemi ML, Hemminki K, Sallunén M. Application of hospital discharge register for studies on spontaneous abortions. In: Hemminki $\mathbf{K}$, Sorsa $\mathbf{M}$, Vainio $\mathbf{H}$, eds. Occuaptional hazards and reproduction. Washington DC: Hemisphere Publishing Co (in press). 